\title{
SZÉLTEHER NAPELEMEKEN
}

\section{WIND LOADING ON SOLAR PANELS}

\author{
Sauca Ana Camelia, ${ }^{1}$ Milchiș Tudor, ${ }^{2}$ Gobesz Ferdinánd-Zsongor ${ }^{3}$ \\ Kolozsvári Müszaki Egyetem, Építőmérnöki Kar, Kolozsvár, Románia \\ ${ }^{1}$ camelianna@yahoo.com \\ ${ }^{2}$ tudor.milchis@mecon.utcluj.ro \\ ${ }^{3}$ go@mecon.utcluj.ro
}

\begin{abstract}
A fully 3D numerical analysis of turbulent flow over a cluster of solar photovoltaic (PV) panels was performed in order to assess the total drag and lift forces, comparing the results with the values from the guidelines of the national standard. A Reynolds-Averaged Navier-Stokes (RANS) model was used in the numerical simulations, considering two acting directions of the wind along the length of the array ( 0 degree - front, and 180 degrees - reverse direction).
\end{abstract}

Keywords: wind load, drag and lift forces, solar photovoltaic panel (PV), Computational Fluid Dynamics (CFD), RANS.

\section{Összefoglalás}

Napelemes panelekből kialakított szerkezetsorra ható, turbulens légáramlatból származó, eltoló- és emelőerők eredőjének a megállapítása végett térbeli számszerű vizsgálatot hajtottunk végre, majd a kapott értékeket hasonlítottuk össze a nemzeti szabvány előírásai szerint számítottakkal. A numerikus szimuláció során Reynolds-állagolt Navier-Stokes (RANS) modellt alkalmaztunk, két szélirányt feltételezve a szerkezetsor tengelye irányában ( 0 fok - elölről, illetve 180 fok - hátulról).

Kulcsszavak: szélteher, eltoló- és emelőerők, napelemes panel, számítógépes folyadék dinamika (CFD), RANS.

\section{Bevezetés}

A napenergia hasznosítása általában fotovoltaikus (PV) napelemekből kialakított panelek segítségével történik. A panelek mérete és száma a napelemek teljesítményétől és a kimenetként igényelt energiamennyiségtől függ. A panelek szerkezeti méretezéséhez ismerni kell a rájuk ható erőket. A tolóerők (nyomás) meg az emelőerők (szívás) eredője különféle értékeket kaphat, a panelek földhöz viszonyított dőlésszögének függvényében.

Az elmúlt években több kutató végzett széles körü tanulmányokat a napelemes panelek szélterheléséről. Néhány tanulmány keretében csak egy elszigetelt panelt vizsgáltak, de a nyomó- meg szívóhatások eredőjének a számításához nagyon sok szélirányra és dőlésszögre vonatkozó hipotézissel. Az egyik ilyen dolgozat az [1]-es, melyben kiterjedt numerikus vizsgálat van leírva több szélirány számításba vételével (0-tól 90 fokig) egy $30^{\circ}$-os dőlésszögű panel esetében. Skalált szélcsatorna-kísérletet és numerikus szimulációt Ogedengbe és társai [2] dolgozatában találunk, egy napelemmodulra, még több széliránnyal (0-tól 180 fokig), de más hasonló vizsgálatok eredményeit is érdemes a $[3,4,5]$ dolgozatokban átnézni. Más kutatók panelcsoportokra végeztek numerikus vizsgálatokat és skalált szélcsatornakísérleteket [6, 7, 8, 9]. Ezek a szerkezetek csupán 
mértani alakjuk miatt tűnnek egyszerűeknek. A körülöttük keletkező áramlatok turbulensek, így a szélből keletkező terhelőerők pontos megállapítása nem egyszerü.

Több paraméter befolyásolja a terhelőerők értékeit (a földtől való magasság, a panelek méretei és dőlésszöge stb.), ezek közül a szélirány a legjelentősebb. Nem könnyű ilyen sok paraméter által befolyásolt szélteher hatására megállapítani a szerkezet valószínűsíthető válaszát, majd ez alapján megfelelően megtervezni és megépíteni egy üres mező közepére, ahol erős szél meg széllökések érhetik. Emiatt, biztonsági megfontolásokból, a tervezési szabványok túlértékelik az ilyen szerkezetekre ható erőket. Ez a magyarázata, hogy nem sok szerkezet ment tönkre helyi hatások miatt.

Az összetett napelemes panelszerkezetek esetében a nyomó- és húzóterhek eredőjének a megállapításához nincs megfelelően részletes eljárás a jelenlegi romániai tervezési előírásokban. A szélteherre vonatkozó együtthatók értékeinek a számítása mind az Eurokód 1-ben (SR EN 1991-1-4), mind a nemzeti szabványban (CR-1-14-2012) csupán egyedülálló panelszerkezetre van leírva. A jelen tanulmányban két összetett szerkezetet vizsgáltunk annak érdekében, hogy felmér- jük az őket alkotó panelekre jutó szélterhek értékeit. Ezek a szerkezetek összetettebbek, a szélteherre kialakuló válaszuk sem egyszerü, így teljes szerkezeti vizsgálat helyett csupán a terhelőerők meghatározását tűztük ki célul.

A szerkezetek geometriai alakja nagyon magas Reynolds-értékhez vezetett (106-os szintűhöz), így turbulens áramlási modellt kellett alkalmaznunk. A tompa testek szélterhelési értékei különösen fontosak a nagy panelek, hirdetőtáblák szerkezeteinek a kialakításakor. A tompa test körüli áramlatokban megjelenő örvényekre a Reynoldsszám magas értéke utal, tükrözve a test körüli légáramlás milyenségét. A test alakjának mértani sajátosságai is befolyásolják a nyomó- és húzóterhek értékeit, még akkor is, ha a test aprócska, így elengedhetetlen egy teljes térbeli numerikus számítási modell alkalmazása a vizsgálathoz, amenynyiben erre számítástechnikai lehetőség létezik.

$\mathrm{Az}$ ország napsütés intenzitási térképének (1. ábra) alapján ki lehet választani a fotovoltaikus panelekből álló napfarmok elhelyezésének a legmegfelelőbb helyeit. Míg a délre fekvő területeket főként mezőgazdasági célokra használják, az esetünkben az ország középső részére esett a választás, ahol a felszín dombosabb, hegyesebb,

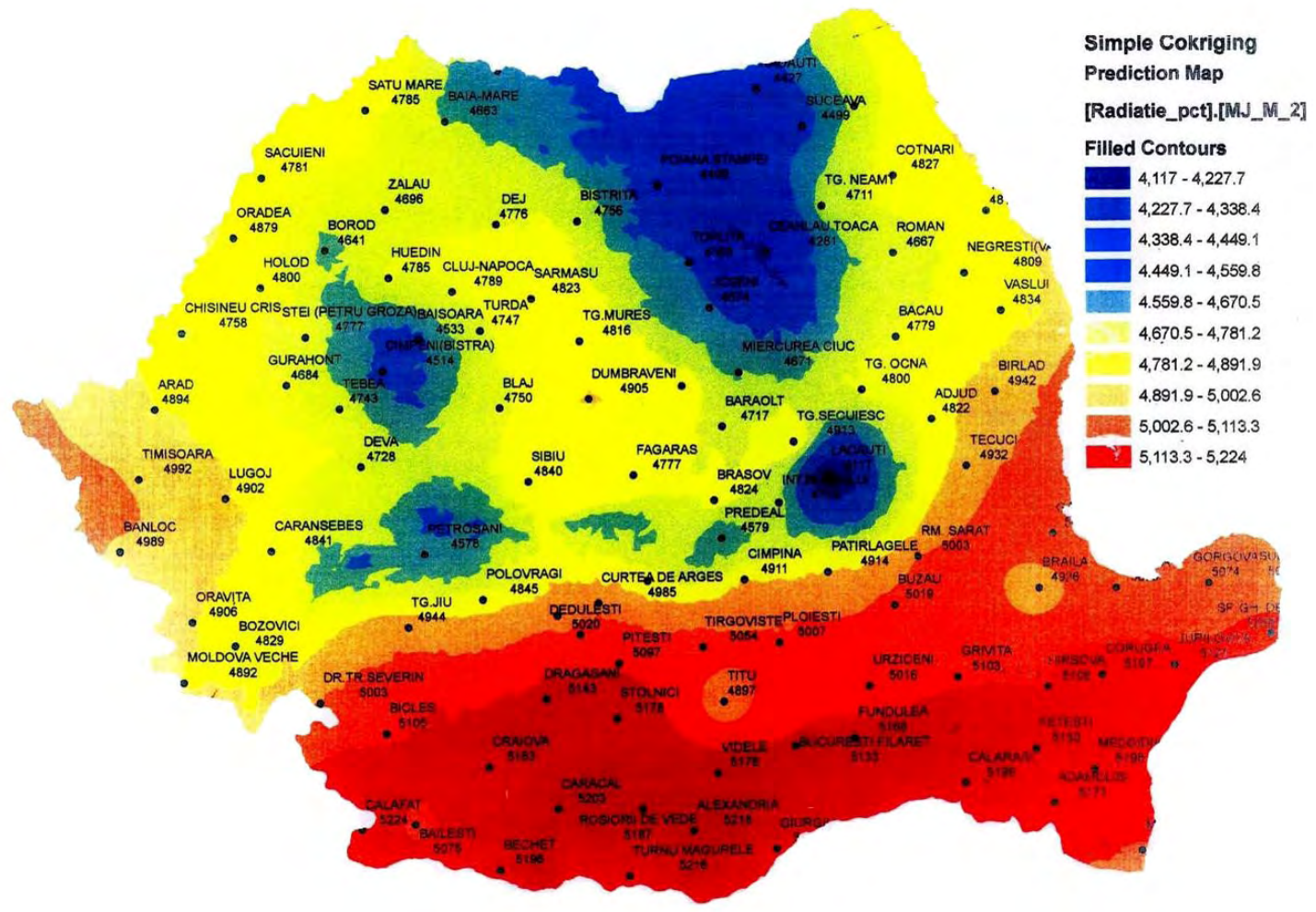

1. ábra. Románia napsugárzási térképe [10] 
így a szélsebesség is nagyobb, mint a délre fekvő sík vidéken.

A napelemes paneleket a legtöbb esetben szögletes acélkeretre szerelt fotovoltaikus lapok sík sorozatából állítják össze, melyek dőlésszöge a nap felé irányul (2. ábra). Vannak fejlettebb változatok is, melyek a nap útját képesek követni az égbolton, ezek általában ívelt alakban készülnek.

\section{Numerikus modell}

Két szerkezet vizsgálatát végeztük el, előbb egy négy panelből álló sorét (A eset), majd egy hét panelből álló sorét (B eset). Mindkét esetnél azonos paneltípusok szerepeltek, $2 \mathrm{~cm}$ köztes hézaggal szerelt 24 kisebb napelemes lapból kialakítva. Ekképp, egy panel hossza szinte $10 \mathrm{~m}$, szélessége kevéssel $3 \mathrm{~m}$ felett van (3. ábra). A panelek egy-

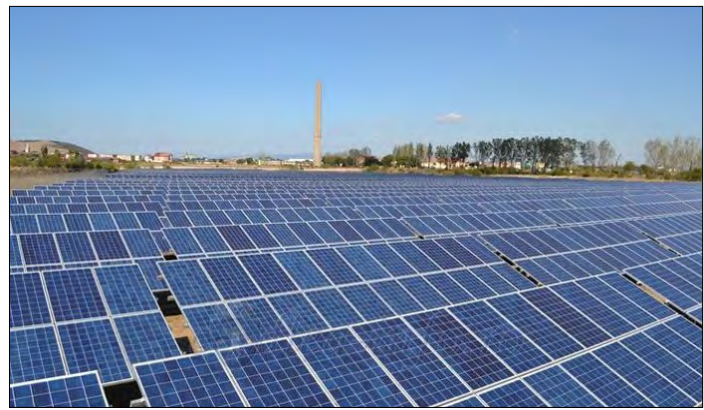

2. ábra. Napelemekből összeállított panelsorozat [11]

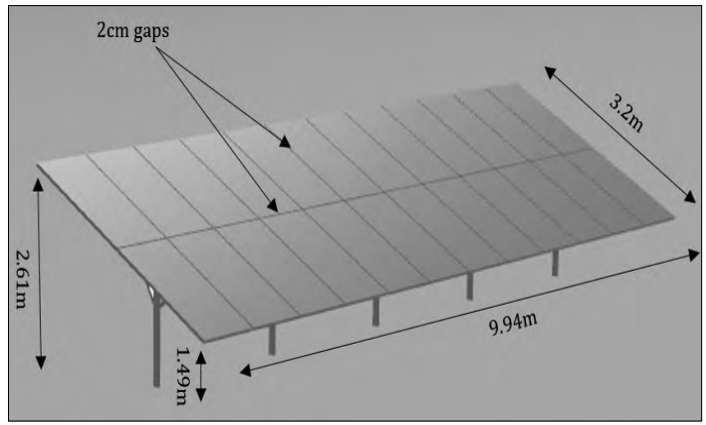

3. ábra. A panel kialakítása (24 sík napelemből) mástól 5 m-es távolságra, 25 fokos dőlésszöggel vannak a talaj felett elhelyezve (4. ábra).

Annak érdekében, hogy a turbulens légáramlást figyelembe véve elfogadható eredményeket lehessen kapni, a numerikus szimulációkhoz egy $52 \times 130 \times 10 \mathrm{~m}$ térfogatú tartomány lett modellezve Ansysban, amint azt az 5. ábra mutatja (bár az A esetnél kisebb tartományt lehetett volna használni).

A megfelelő konvergencia biztosítása végett a modell felosztása igen sok véges elemet igényelt, így strukturált hálózást alkalmaztunk (a „cut-cell” eljárással). A legapróbb véges elem $5 \mathrm{E}-3 \mathrm{~m}$ széles, az első réteg magassága 1E-3 $\mathrm{m}$ és a növekedési arány 1,2 lett. Végül a kialakított hálós tartomány 8,7E+6 csomópontot és 7,5E+6 elemet tartalmazott a $B$ esetnél (lényegesen többet, mint az A esetben). A 6. ábra a hálózási sűrüség változását szemlélteti a panelek közelében.

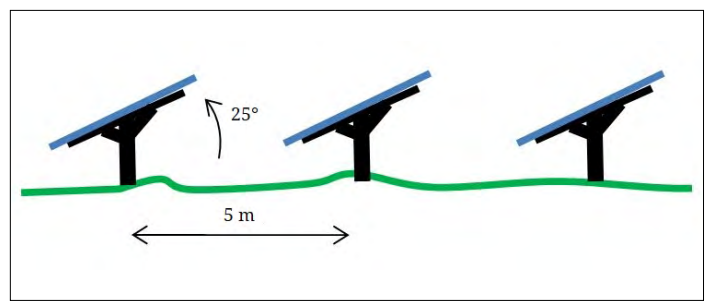

4. ábra. A panelsorok kialakítása

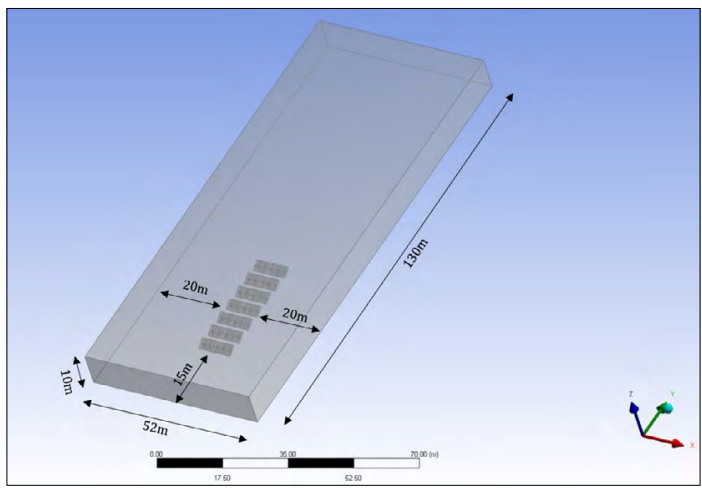

5. ábra. A numerikus szimulációhoz modellezett tartomány (B eset)

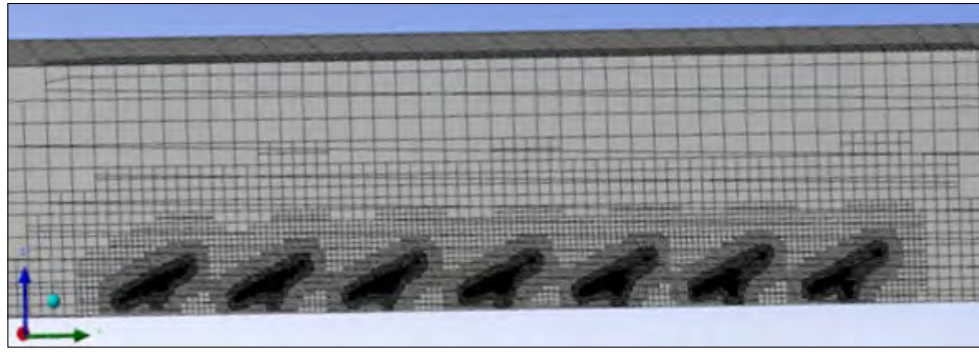

6. ábra. A hálózási sürüség változása felületközelben (B eset) 
Az áramlási tartomány peremfeltételeit a 7. ábra szemlélteti. Az A esetben módosítás lett eszközölve úgy, hogy a folyadéktartomány felső és oldalsó szélei falakként lettek kezelve (ami csúszás- meg behatolásmentességet jelent). A két megközelítés közötti különbségek nem bizonyultak relevánsnak a végeredmények szempontjából, így azt mondhatjuk, hogy ha elég nagy térfogatú tartományt modellezünk, akkor mindkét feltétel megfelel.

A RANS-egyenletek megoldására alkalmazott matematikai modell egy javított falkezeléssel ellátott turbulens áramlású $\mathrm{k}-\varepsilon$ változat volt. Mindkét esetben csak két szélirány-hipotézis lett figyelembe véve $\left(0^{\circ}\right.$ - elölről és $180^{\circ}$ - hátulról, a leghátrányosabb terhelési esetek). Így a numerikus vizsgálatok négy hipotézisre vonatkoztak, amelyek a következőképp lettek jelölve: A-front és A-back (A eset), B-front és B-back (B eset), a szél irányának megfelelően.

Mind a négy (A eset), mind a hét (B eset) panelből álló sorozat esetében a folyadéktartomány beállításai azonosak voltak, a megfigyelt folyadéká-

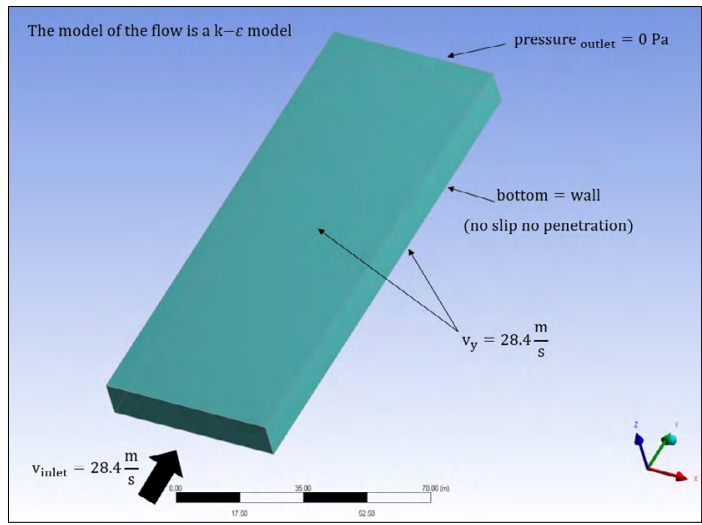

7. ábra. Az áramlási tartomány peremfeltételei

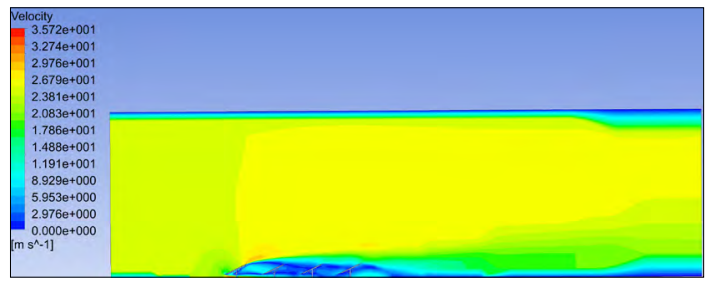

8. ábra. A szél sebességeloszlása az A-front esetben

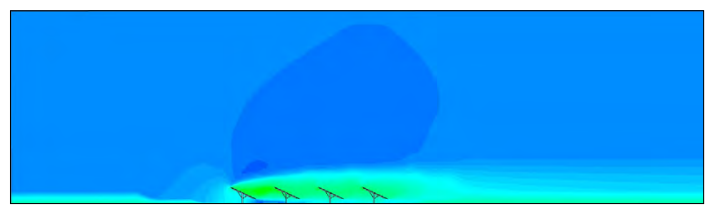

9. ábra. A szél sebességeloszlása az A-back esetben ramlás és a turbulencia intenzitása is hasonlónak bizonyult, csak a nyomó- és szívóterhek értékei lettek mások.

\subsection{Az A eset eredményei}

Az áramlási sebességeloszlást a 8. ábra (A-front) és a 9. ábra (A-back) mutatja a sorozat hosszirányú tengelyével párhuzamos síkban. A szélirány a kép bal oldaláról a kép jobb oldala felé van mindkét ábrán.

A nyomó- és szívóhatások eredői az A eset említett két szélirányára az 1 . és 2 . táblázatban láthatók.

\subsection{A B eset eredményei}

$\mathrm{Az}$ áramlási sebességeloszlást a 10. ábra (B-front) és a 11. ábra (B-back) mutatja a sorozat hosszirányú tengelyével párhuzamos síkban. A szélirány a kép bal oldaláról a kép jobb olda-

1. táblázat. Nyomó- és szívóterhek eredői [N], A-front eset

\begin{tabular}{|l|c|c|}
\hline \multicolumn{1}{|c|}{ Panel } & Nyomás (Y axis) & Szívás (Z axis) \\
\hline P1 (szél felőli) & 1539,3113 & $-2887,2343$ \\
\hline P2 & 1529,2392 & $-2907,2607$ \\
\hline P3 & 607,91867 & $-949,07348$ \\
\hline P4 (szél alatti) & 4422,9963 & $-8837,388$ \\
\hline
\end{tabular}

2. táblázat. Nyomó- és szívóterhek eredői [N], A-back eset

\begin{tabular}{|l|c|c|}
\hline \multicolumn{1}{|c|}{ Panel } & Nyomás (Y axis) & Szívás (Z axis) \\
\hline P1 (szél felőli) & 2885,4727 & 5840,8222 \\
\hline P2 & 2276,3627 & 4602,1176 \\
\hline P3 & 607,93947 & 1147,551 \\
\hline P4 (szél alatti) & 7325,4916 & 14972,468 \\
\hline
\end{tabular}

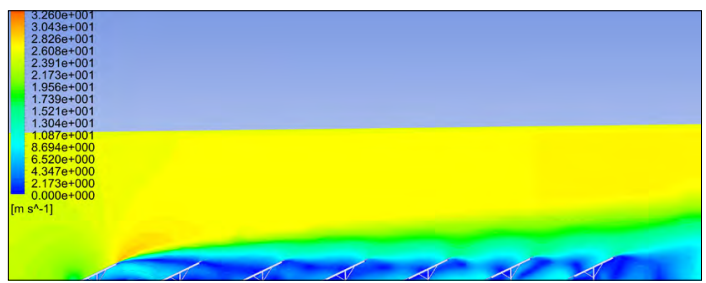

10. ábra. A szél sebességeloszlása a B-front esetben

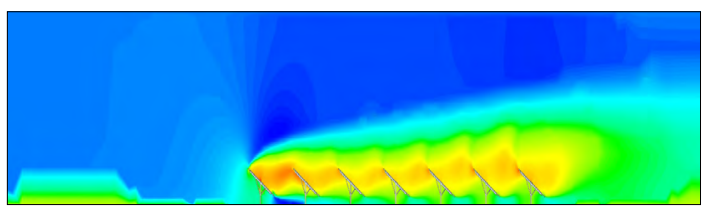

11. ábra. A szél sebességeloszlása a B-back esetben 


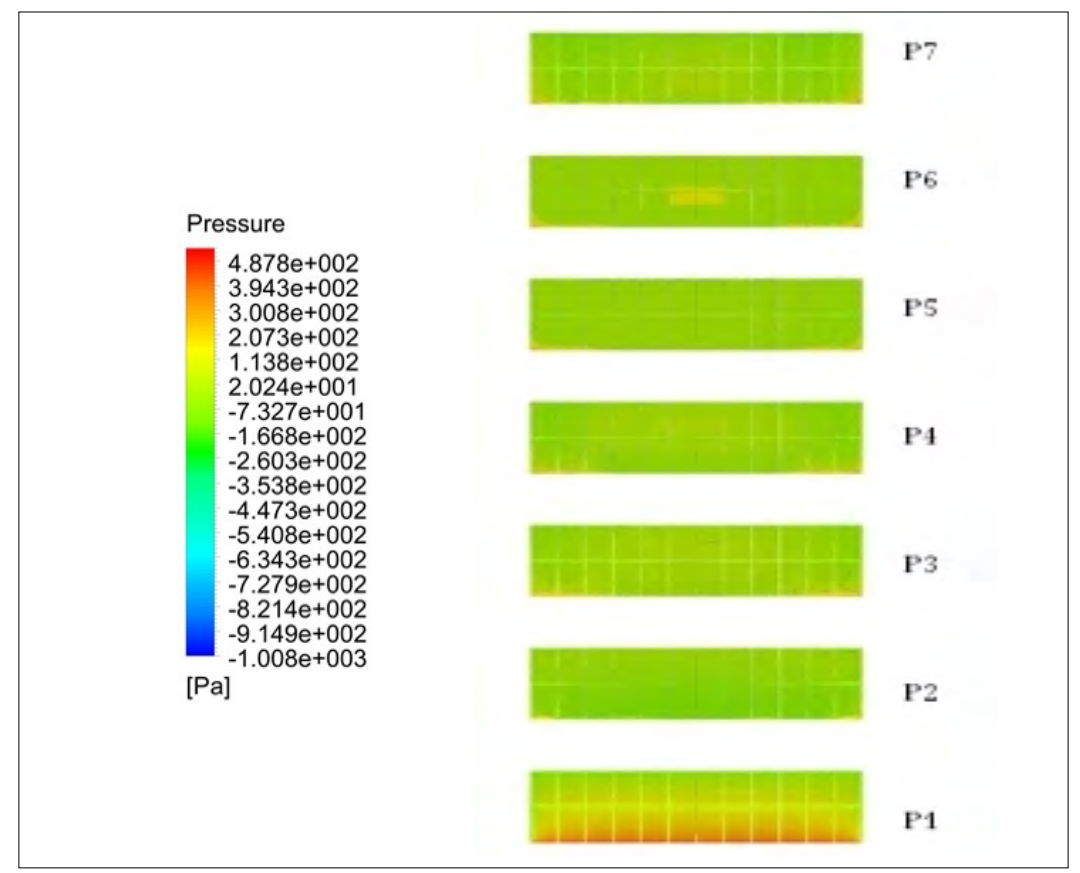

12. ábra. Nyomáseloszlás a paneleken (B-front)

la felé van mindkét ábrán. A nyomáseloszlás a B-front esetben pedig a 12. ábrán látható. A nyomó- és szívóhatások eredői a B eset két szélirányára a 3. és 4. táblázatban vannak feltüntetve.

3. táblázat. Nyomó- és szívóterhek eredői [N], B-front

\begin{tabular}{|l|c|c|}
\hline \multicolumn{1}{|c|}{ Panel } & Nyomás (Y axis) & Szívás (Z axis) \\
\hline P1 (szél felőli) & 4613,7123 & $-9182,1861$ \\
\hline P2 & 583,24925 & $-1065,778$ \\
\hline P3 & 1330,112 & $-2601,6572$ \\
\hline P4 & 1172,4369 & $-2251,5358$ \\
\hline P5 & 1572,6932 & $-3079,4485$ \\
\hline P6 & 1841,3657 & $-3654,8858$ \\
\hline P7 (szél alatti) & 1934,8247 & $-3850,5414$ \\
\hline
\end{tabular}

4. táblázat. Nyomó- és szívóterhek eredői [N], B-back

\begin{tabular}{|l|c|c|}
\hline \multicolumn{1}{|c|}{ Panel } & Nyomás (Y axis) & Szívás (Z axis) \\
\hline P1 (szél alatti) & 2949,8167 & 5949,4786 \\
\hline P2 & 2505,5557 & 5062,3157 \\
\hline P3 & 2276,3973 & 4498,6831 \\
\hline P4 & 2194,8544 & 4348,1134 \\
\hline P5 & 2104,1257 & 4257,0653 \\
\hline P6 & 316,37399 & 613,9565 \\
\hline P7 (szél felőli) & 7311,7861 & 15219,223 \\
\hline
\end{tabular}

\section{Következtetések}

A vizsgálat során a szélterhelést számszerű szimuláció (CFD) segítségével állapítottuk meg a napelemes panelsorok két konfigurációjára, az első és a hátsó szélirányokat figyelembe véve. Avégett, hogy össze lehessen hasonlítani a számszerű eredményeket a szabványból származókkal, kézi számítást végeztünk a CR-1-1-4-2012 előírásai szerint:

- a szerkezetek földrajzi helyének megfelelő szél referencianyomása $q_{b}=0,5 \mathrm{kN} / \mathrm{m}^{2}$, ebből az értékből származó szélsebesség $v \approx 28,4 \mathrm{~m} / \mathrm{s}$ (ugyanaz, mint a numerikus szimulációban);

- a szél irányában megjelenő teljes nyomóteher, a panelekre eső nyomás esetében, $\mathrm{F}_{\mathrm{w}}{ }^{\mathrm{ny}}=10598 \mathrm{~N}$ $(10,6 \mathrm{kN})$ lett;

- a szél irányában megjelenő teljes húzóerő, a panelekre jutó szívás esetében, $\mathrm{F}_{\mathrm{w}}^{\mathrm{sz}}=-16957 \mathrm{~N}$ $(17,0 \mathrm{kN})$ lett;

Összevetve ezeket az értékeket a CFD szimulációval kapottakkal, nyilvánvaló, hogy a nemzeti kód túlbecsüli a teljes nyomó- és szívóterhet, főként azért, mert egyedül álló panelt vesz figyelembe. Egyedül álló panel esetén a teljes szélterhet ő kell átvegye.

A kézzel számított és a numerikus szimulációval kapott értékek közötti eltérések 31\% körül vannak a nyomóteher, és $10 \%$ felett a húzóteher esetében. 


\section{Szakirodalmi hivatkozások}

[1] Agarwal A., Irtaza H., Zameel A.: Numerical study of lift and drag coefficients on a ground-mounted photovoltaic solar panel. Materials Today: Proceedings 4/9. (2017) 9822-9827. https://doi.org/10.1016/j.matpr.2017.06.274

[2] Abiola-Ogedengbe A., Hangan H., Siddiqui K.: Experimental investigation of wind effects on a standalone photovoltaic (PV) module. Renew. Energy, 78. (2015) 657-665. https://doi.org/10.1016/j.renene.2015.01.037

[3] Jubayer C. M., Hangan H.: Numerical simulation of wind effects on a standalone ground mounted Photovoltaic $(P V)$ system. Journal of Wind Engineering and Industrial Aerodynamics 134. (2014) 56-64. https://doi.org/10.1016/j.jweia.2014.08.008

[4] Mier-Torrecilla M., Herrera E., Doblaré M.: $\mathrm{Nu}$ merical calculation of wind loads over solar collectors. Energy Procedia, 49. (2013) 163-173. https://doi.org/10.1016/j.egypro.2014.03.018

[5] Reina G. P., De Stefano G.: Computational evaluation of wind loads on sun-tracking ground-mounted photovoltaic panel arrays. Journal of Wind Engineering and Industrial Aerodynamics, 170. (2017) 283-293.

https://doi.org/10.1016/j.jweia.2017.09.002
[6] Jubayer C. M., Hangan H.: A numerical approach to the investigation of wind loading on an array of ground mounted solar photovoltaic (PV) panels. Journal of Wind Engineering and Industrial Aerodynamics, 153. (2016) 60-70. https://doi.org/10.1016/j.jweia.2016.03.009

[7] Warsido W. P., Bitsuamlak G. T., Barata J., Gan Chowdhury A.: Influence of spacing parameters on the wind loading of solar array. Journal of Fluids and Structures, 48. (2014) 295-315. https://doi.org/10.1016/j.jfluidstructs.2014.03.005

[8] Cain J. H., Banks D.: Wind Loads on Utility Scale Solar PV Power Plants. 2015 SEAOC Convention Proceedings. 1-8.

[9] Alluri S. K. R., Shit T., Gujjula D., Phani Kumar S. V. S., Ramana Murthy M. V.: Feasibility study on fixed platforms for offshore wind turbine in India. Journal of Structural Engineering (India), 41/1. (2014) 1248-1256. https://doi.org/10.3850/978-981-07-8012-8_262

[10] Energy Street: Global solar radiations (letöltve 2018. november 20.)

http://energystreet.ro/en/photovoltaic/romania-solar-map

[11] Kelvin PDC: Panouri solare fotovoltaice (letöltve 2018. nov. 20.)

http://pompedecaldura2005.ro/echipamente/panouri-solare-fotovoltaic/\#.W_azih8lGkB 